\title{
RAM EFFECT ON ESTRUS BEHAVIOR, OVARIAN STRUCTURE AND STEROID HORMONE LEVELS IN OSSIMI EWES TREATED WITH PROSTAGLANDIN F $_{2 \alpha}$ FOR ESTRUS SYNCHRONIZATION
}

\author{
G.B. Mahmoud ${ }^{1}$ and H. A. Hussein ${ }^{2}$
}

1- Animal Production Department, Agriculture Faculty, 2 - Theriogenology Department, Veterinary Medicine Faculty, 1,2- Assiut University, 71526, Assiut, Egypt

Received: $12 / 12 / 2018$

Accepted: 9/2/2019

\section{SUMMARY}

The objective of this study was to assess presence of ram with prostaglandin $F_{2 \alpha}\left(P G F_{2 \alpha}\right)$ on estrus behavior, patterns offollicular growth and steroid hormone production of Ossimi ewes in subtropics. Ewes $(n=20)$, were isolated from rams 30 days and thereafter, prostaglandin $F_{2 \alpha}\left(P G F_{2 \alpha}\right)$ was used for synchronization by two injections 10 days apart. Ewes were randomly divided into two equal groups $(n=10)$. The first group, $P G F_{2 \alpha}$ with ram effect (PGRE), ewes were exposed to two trained teaser rams at the time of the second $P G F_{2 \alpha}$ injection until the end of the experiment, whilst the second group (PG), ewes were isolated from rams except at the time for estrus detection. Estrus behavior and time of ovulation were detected after the second prostaglandin injection by noting the responses of the ewes to the male in the pen and by ultrasonography. The number and size of all follicles $\geq 2 \mathrm{~mm}$ and corpus luteum (CL) were monitored by ultrasonography. Blood samples were collected for measuring estradiol $-17 \beta\left(E_{2}\right)$ and progesterone $\left(P_{4}\right)$ hormones. Onset of estrus, time of ovulation and estrous cycle length were significantly shorter $(P<0.05)$ in PGRE group compared with PG group. The number of preovulatory follicles and the mean size of ovulatory follicles were higher $(P<0.05)$ in PGRE group compared with those in PG group. Moreover, the mean ovulation rate was higher $(P<0.05)$ in PGRE group than that in $P G$ group. In addition, the production of $P_{4}$ was greater $(P<0.05)$ in $P G R E$ group on days 10 and 14 of the estrous cycle compared to the ewes in $P G$ group. While, concentrations of the $P_{4}$ were increased numerically in PGRE group during 0, 2, 6 and 8 d of the estrous cycle. E $E_{2}$ production was almost similar in both groups.

In conclusion, the presence of rams combined with $P G F_{2 \alpha}$ treatment, hastens estrus onset, decreased the time of ovulation, increased the ovulation rate and ovarian activity of Ossimi ewes in subtropical areas.

Keywords: Ram effect, estrus behavior, ovarian structure, steroid hormones

\section{INTRODUCTION}

Estrus synchronization of ewes is the main element of the reproductive management in sheep breeding. Two injections of prostaglandin $\left(\mathrm{PGF}_{2 \alpha}\right)$ are widely used for estrus synchronization in cyclic ewes and control of the reproduction manages in the breeding season (Fierro et al., 2013). The estrus synchronization by $\mathrm{PGF}_{2 \alpha}$ is a relatively low cost, good, quickly and almost the ewes at the time of the second dose of $\mathrm{PGF}_{2 \alpha}$ in mid luteal phase and become in estrus (Abecia et al., 2012).

The sudden exposure of rams to seasonal anestrous ewes after period of is olated (phenomenon, ram effect), induces behavior of estrus, ovulations and parturition (Martin et al., 1986; Ungerfeld et al., 2004 and Delgadillo et al., 2009). The release of LH surge in anestrous ewes appears to be due to the presence of ram and resulted in ovulation (Hawken and Martin, 2012; Jorre de St. Jorre et al., 2014; Fabre-Nys et al., 2016 and Ferreira-Silva et al., 2017 $\mathrm{ab}$ ). Also, the LH surge was released after introduction of the ram to cyclic ewes during breeding season of all stages of the estrous cycle (Hawken et al., 2007). The continuous presence of rams during the follicular phase increases the $\mathrm{LH}$ surge and hastens the onset of estrus (Fletcher and Lindsay, 1971; Lindsay et al., 1975; Ungerfeld and Rubianes, 1999 and Contreras-Solis et al., 2009). Additionally, the ram effect becomes widespread use in the 'Mediterranean' genotypes (Folch, 1990; Rosa and Bryant, 2002 and Ungerfeld et al., 2004). Although the ram effect widely used in ewes of anestrous season, however, its possible applications in cyclic ewes have scarcely studied. Thus, the $\mathrm{PGF}_{2 \alpha}$ with presence of the ram may be a useful tool for flock management. Thus, the objective of the present study was to investigate the ram effect combined with $\mathrm{PGF}_{2 \alpha}$ estrus synchronization on estrus behavior, patterns of follicular growth and estradiol$17 \beta\left(\mathrm{E}_{2}\right)$ and progesterone $\left(\mathrm{P}_{4}\right)$ hormones production of Ossimi ewes in subtropics.

\section{MATERIALS AND METHODS}

\section{Animals and experimental design:}

The trial was conducted on the experimental farm of Agriculture Faculty, Assiut University, Assiut, Egypt. Twenty multiparous Ossimi ewes (4-5 years old and average body weight $46.1 \pm 1.3 \mathrm{~kg}$ ), 
raised in semi-open pens were used for this experiment. The experiment conducted during autumn season (September-October). Experimental diet used for feeding the ewes was formulated according to NRC (1985). Water and trace mineral salt were available all days.

All ewes were isolated from males for 30 days (Ferreira-Silvaet al., 2018) and thereafter were synchronized using two intramuscular injections of $250 \mu \mathrm{g} / \mathrm{mL}$ of $\mathrm{PGF}_{2 \alpha}$ analog (cloprostenol) 10 days apart. Ewes were randomly divided into two equal groups, 10 ewes each, balanced for body weight and parity. The first group, ewes were injected with $\mathrm{PGF}_{2 \alpha}$ in association with ram effect (PGRE). Ewes were exposed to two trained teaser rams at the timing of the second $\mathrm{PGF}_{2 \alpha}$ injection (Day 0 for the trial) until the end of the experiment. While, the second group (PG) ewes were isolated from rams after the second $\mathrm{PGF}_{2 \alpha}$ injection except at the time where rams were introduced for estrus detection.

\section{Estrus observation:}

Estrus behavior was detected twice daily (8.0 a.m. and 4.0 p.m.) after the second prostaglandin injection by noting the responses of the ewes to the male in the pen using trained teaser rams and ultrasonography was carried out daily to monitor the occurrence of ovulation.

The onset of estrus (interval from the second $\mathrm{PGF}_{2 \alpha}$ injection to the first time ewes were receptive to the males). The estrous cycle length was determined as the interval between two successive heats or ovulations.

\section{Ultrasound monitoring of ovarian structures:}

From one day prior the second $\mathrm{PGF}_{2 \alpha}$ dose, all follicles number and size $\geq 2 \mathrm{~mm}$ were monitored daily by transrectal ultrasound scanning (Pie Medical, 100 LC, Holland) having a 6-8 MHz end of rectal probe (Lv513). The probe was turn in the rectum $90^{\circ}$ clockwise and $180^{\circ}$ anticlockwise for ovaries scanning in the standing ewe. The number and diameter of larger follicles were detected and evaluation by sketches that given the size for each follicle. The ovulation rate was recorded, when the largest follicles (> $5 \mathrm{~mm}$ ) identified and followed without constant observation that considered the ovulation have occurred. The CL was examined and an image of the maximum diameter from the largest cross-sectional area was estimated.

\section{Blood sampling and hormonal analysis:}

After the second $\mathrm{PGF}_{2 \alpha}$ dose, blood samples were collected daily from jugular vein during the days of the estrous cycle before feeding on the morning. Samples of blood were centrifuged for 20 minutes at $2000 \times \mathrm{g}$, thereafter, serum was harvested and stored at $-20{ }^{\circ} \mathrm{C}$. Progesterone and Estradiol-17 $\beta$ hormonal levels were executed by ELISA technique. Laboratory Diagnostic System Co. (Catalogue No.
3900, DSL, USA) gave Kits. The variations coefficients of the intra- and inter assay were $3.6 \%$ and $12.43 \%$ for progesterone and $4.8 \%$ and $9.2 \%$, for Estradiol-17 $\beta$, respectively. Assay sensitivity was $0.12 \mathrm{ng}$ for progesterone and $2 \mathrm{pg}$ for Estradiol-17 $\beta$.

\section{Statistical analysis:}

Statistical analyses were done using SPSS package (2007). The mean differences between the two groups regarding the estrus onset, ovulation time, the number and size of the ovulatory follicles, length of the estrous cycle, $\mathrm{E}_{2}$ and $\mathrm{P}_{4}$ hormones were estimated by independent t-test (Senosy et al., 2017). Values of probability less than 0.05 were considered significant. The results were expressed as means \pm SEM.

\section{RESULTS AND DISCUSSION}

\section{Estrus behavior:}

The results in terms of estrus characters are presented in Table 1. Estrus was detected in all ewes. Similarly, in previous studies Contreras-Solis et al. (2009) and Abecia et al. (2012) found that, ewes responded to injection of the second $\mathrm{PGF}_{2 \alpha}$ and showed luteolysis and detected in estrus. Abecia et al. (2012) reported that, in tropical breeds, synchronization of estrus required two doses of $\mathrm{PGF}_{2 \alpha} 10$ days apart, whereas, most females will be in the mid-luteal phase and will be detected in estrus and occurrence of ovulation.

The onset of heat $(41.1 \pm 2.4 \mathrm{~h})$ and time of ovulation $(72.6 \pm 2.2 \mathrm{~h})$ in PGRE group were shorter $(\mathrm{P}<0.05)$ than in $\mathrm{PG}$ group $(60.0 \pm 2.6$ and $96.0 \pm 2.5$ h), respectively. Also, the estrous cycle length $(17.4 \pm 0.2)$ was shorter $(\mathrm{P}<0.05)$ in $\mathrm{PGRE}$ group compared with the PG group (20.3 \pm 0.6$)$. This agrees with the results of Hawken et al. (2007) who mentioned that, exposure of cyclic ewes to rams stimulated their response in the breeding season. The rams continuous presence during the follicular phase, increased the LH surge and hasten onset of estrus (Fletcher and Lindsay, 1971; Lindsay et al., 1975; Ungerfeld and Rubianes, 1999 and Contreras-Solis et al., 2009). Furthermore, induced preovulatory LH surge, estrus onset and ovulation time were more accelerated and their occurrence was earlier in ewes when the rams were introduced at the injection timing of the second $\mathrm{PGF}_{2 \alpha}$ compared with the use of two $\mathrm{PGF}_{2 \alpha}$ injections alone (Contreras-Solis et al., 2009; Ungerfeld, 2011 and Meilán and Ungerfeld, 2014). Similarly, in goats, the continuous presence of a male during the breeding season with estrus synchronized females using either progestogens sponges or $\mathrm{PGF}_{2 \alpha}$ and controlled internal drug release (CIDR), hastened onset of estrus, reduced estrus duration and time of ovulation compared with females not exposed to a male (Romano, 1998 and Romano et al., 2016). 
Table 1. Onset of estrus, time of ovulation and estrous cycle length in ewes synchronized by prostaglandin $\left(\mathrm{PGF}_{2 \alpha}\right)$ with or without ram effect

\begin{tabular}{cccc}
\hline Group & $\begin{array}{c}\text { Onset of estrus } \\
(\mathbf{h})\end{array}$ & $\begin{array}{c}\text { Ovulation time } \\
(\mathbf{h})\end{array}$ & $\begin{array}{c}\text { Estrous cycle length } \\
(\mathbf{d})\end{array}$ \\
\hline PGRE & $41.1 \pm 2.4^{\mathrm{a}}$ & $72.6 \pm 2.2^{\mathrm{a}}$ & $17.4 \pm 0.2^{\mathrm{a}}$ \\
PG & $60.0 \pm 2.6^{\mathrm{b}}$ & $96.0 \pm 2.5^{\mathrm{b}}$ & $20.3 \pm 0.6^{\mathrm{b}}$ \\
\hline
\end{tabular}

PGRE; PGF $2 \alpha$ with ram effect, ewes were exposed to two trained teaser rams at the timing of the second PGF $_{2 \alpha}$ injection (Day 0 of the trial) until the end of the experiment. PG: ewes were isolated from rams after the second PGF $_{2 \alpha}$ injection except at the time for estrus detection.

${ }^{\mathrm{a}-\mathrm{b}}$ Means within the same column differed significantly $(P<0.05)$.

\section{Follicular growth:}

The patterns of follicular development are shown in Table 2. The number of preovulatory follicles (4.8 \pm 0.1$)$ and the mean size of the ovulatory follicles $(6.01 \pm 0.0 \mathrm{~mm})$ were higher $(\mathrm{P}<0.05)$ in $\mathrm{PGRE}$ group than in PG group $(3.9 \pm 0.1$ and $5.20 \pm 0.0 \mathrm{~mm})$, respectively. The ovulation rate in PGRE group was higher $(\mathrm{P}<0.05)$ than that in $\mathrm{PG}$ group $(1.40 \pm 0.2 v s$ $1.00 \pm 0)$. These results are in agreement with those of Rubianes et al. (1997) and Ferreira-Silva et al. (2018) who indicated that, the number and size of the larger follicles and ovulatory follicles were increased after introduction of the rams to ewes. Moreover, FSH level and LH surge increased in ewes as an endocrine response to the presence of the ram(Ungerfeld et al., 2000 and Ungerfeld, 2003). The continuous presence of rams with ewes increased LH surge and enhanced the ovarian activity (Murtagh et al., 1984 and Folch, 1990). However, the LH pulsatility was the main effect on the growth of preovulatory follicular and it coincided with the increase in the large follicles number and largest follicle diameter (Baird and McNeilly, 1981 and Ungerfeld, 2003). Preovulatory LH peaks occurred in ewes, due to the presence of rams that acts upon this role of the growth of the ovarian follicles (Ferreira-Silva et al., 2017 ab and Ferreira-Silva et al., 2018).

Table 2. Characteristics of the follicular populations and corpus luteum (CL) in ewes synchronized by prostaglandin $\left(\mathbf{P G F}_{2 \alpha}\right)$ with or without ram effect

\begin{tabular}{ccccc}
\hline Group & Follicles $\leq \mathbf{5} \mathbf{~ m m}$ & $\begin{array}{c}\text { Ovulatory follicles } \\
(\mathbf{m m})\end{array}$ & Ovulation rate & $\begin{array}{c}\text { CL diameter } \\
(\mathbf{c m})\end{array}$ \\
\hline PGRE & $4.8 \pm 0.1^{\mathrm{a}}$ & $6.01 \pm 0.0^{\mathrm{a}}$ & $1.40 \pm 0.2^{\mathrm{a}}$ & $1.24 \pm 0.0$ \\
PG & $3.9 \pm 0.1^{\mathrm{b}}$ & $5.20 \pm 0.0^{\mathrm{b}}$ & $1.00 \pm 0.0^{\mathrm{b}}$ & $1.10 \pm 0.0$
\end{tabular}

PGRE; PGF $F_{2 \alpha}$ with ram effect, ewes were exposed to two trained teaser rams at the timing of the second PGF $_{2 \alpha}$ injection (Day 0 of the trial) until the end of the experiment. PG: remaining ewes were isolated from rams after the second $\mathrm{PGF}_{2 \alpha}$ injection except at the time for estrus detection.

${ }^{\mathrm{a}-\mathrm{b}}$ Means within the same column differed significantly $(\mathrm{P}<0.05)$.

\section{Hormonal profile:}

Concentration of $\mathrm{P}_{4}$ was higher $(\mathrm{P}<0.05)$ in PGRE group on days 10 and 14 of the estrous cycle $(5.3 \pm 0.4$ and $4.6 \pm 0.4 \mathrm{ng} / \mathrm{mL}$ ) compared to the $\mathrm{PG}$ group $(3.9 \pm 0.0$ and $3.2 \pm 0.2 \mathrm{ng} / \mathrm{mL})$, respectively. Moreover, concentrations of $\mathrm{P}_{4}$ increased numerically in PGRE group during $0,2,6$ and $8 \mathrm{~d}$ of the estrous cycle $(0.2 \pm 0.0,1.1 \pm 0.6,2.4 \pm 0.5$ and $3.3 \pm 0.5 \mathrm{ng} / \mathrm{ml})$ than those of the PG group $(0.1 \pm 0.0,0.8 \pm 0.5$, $1.83 \pm 0.92$ and $2.7 \pm 0.2 \mathrm{ng} / \mathrm{ml}$ ), respectively (Fig. 1). These results are in agreement with those of Scaramuzzi et al. (1993) and Godfrey et al. (1999) who indicated that, $\mathrm{P}_{4}$ level was decreased to below 1 $\mathrm{ng} / \mathrm{mL}$ in estrus period and it decreased after the second injection of $\mathrm{PGF}_{2 \alpha}$ (Ganaie et al., 2009). In addition, Homeida et al. (2009) documented that, $\mathrm{P}_{4}$ concentrations on days $2,8,10$ and 14 were $0.4 \pm 0.1$, $1.1 \pm 0.3,4.3 \pm 0.3$ and $2.3 \pm 0.2, \mathrm{ng} / \mathrm{ml}$, respectively in ewes after the second $\mathrm{PGF}_{2 \alpha}$ injection. These results may be due to the continuous presence of rams after the second $\mathrm{PGF}_{2 \alpha}$ injection. Its influences were on ovarian follicle development and the life span of the resulting CL. Introduced rams to ewes, led to increased $\mathrm{LH}$ and FSH secretion these in turn led to increased follicular size and formation of $\mathrm{CL}$ with higher production of $\mathrm{P}_{4}$ (Ferreira-Silva et al., 2018). These notices point out to the importance of follicular growth for $\mathrm{P}_{4}$ production in the following $\mathrm{CL}$ formation. The production and amount of $\mathrm{P}_{4}$ was connected to the health and number of the granulosa and thecal cells in vitro (Niswender et al., 2000 and Niswender, 2002). The initiation of $\mathrm{P}_{4}$ was increased significantly of ewes in estrus after introduction of the rams (Ungerfeld, 2003).

Furthermore, the differences in $\mathrm{E}_{2}$ in all studied days during the estrous cycle were not significant in both groups (Fig. 1). These results may be due to the high levels of $\mathrm{P}_{4}$ concentration during days of the estrous cycle, which affected on $E_{2}$ by negative feedback mechanism (Lassoued et al., 1997). In addition, it is known that, the LH surge increased in ewes, due to the prime step of ram presence with ewes, this caused an increase in preovulatory $\mathrm{LH}$ surge and occurrence of ovulation. The real 
relationship between $\mathrm{E}_{2}$ and $\mathrm{LH}$ at this time is not well established whereas, in the absence of $E_{2}$, the ram introduction can increase $\mathrm{LH}$ in ewes. The pulsatility of LH was increased in ovariectomized ewes although the $\mathrm{E}_{2}$ absence (Rosa and Bryant, 2002).

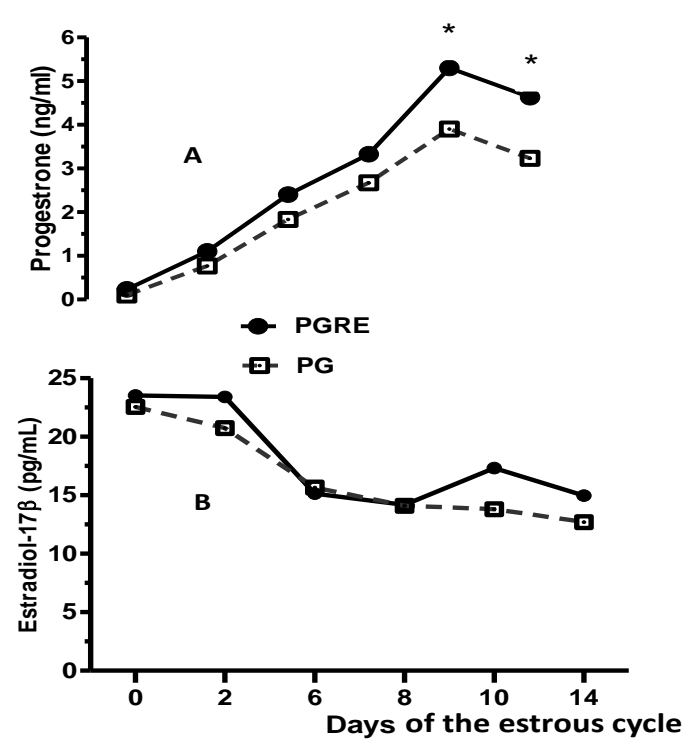

Fig. 1. Changes in serum progesterone $\left(\mathrm{P}_{4} ; \mathrm{A}\right)$ and estradiol-17ß $\left(\mathrm{E}_{2} ; \mathrm{B}\right)$ concentrations in the presence or absence of ram effect. PGRE; PGF $_{2 \alpha}$ with ram effect, ewes were exposed to two trained teaser rams at the timing of the second $\mathrm{PGF}_{2 \alpha}$ injection (Day 0 of the trail) until the end of the experiment. PG: ewes were isolated from rams after the injection of the second $\mathrm{PGF}_{2 \alpha}$.

* Means: The difference between the two groups was significant $(\mathrm{P}<0.05)$.

\section{CONCLUSION}

In conclusion, the present results indicate that, the ram presence combined with $\mathrm{PGF}_{2 \alpha}$ two injections 10 days apart, hasten estrus onset, decreased the time of ovulation, increased the ovulation rate and ovarian activity of Ossimi ewes in subtropical areas.

\section{REFERENCES}

Abecia, J.A., F. Forcada and A. Gonz_alez-Bulnes, 2012. Hormonal control of reproduction in small ruminants. Animal Reproduction Science, 130: 173-179.

Baird, D.T. and A.S. McNeilly, 1981. Gonadotrophic control of follicular development and function during the oestrous cycle of the ewe. Journal of Reproduction and Fertility, (Supplement) 30: 119-133.

Contreras-Solis I, B. Vasquez, T. Diaz, C. Letelier, A. Lopez Sebastian and A. Gonzalez-Bulnes, 2009. Efficiency of estrous synchronization in tropical sheep by combining short-interval cloprostenol-based protocols and "male effect". Theriogenology, 71: 1018-1025.

Delgadillo, J.A., H. Gelez, R. Ungerfeld, P.A.R. Hawken and G.B. Martin, 2009. Revisiting the dogmas surrounding the mechanisms involved in the male effect in sheep and goats. Behavior Brain Research, 200: 304-314.

Fabre-Nys, C., A. Chanvallon, J. Dupont, L. Lardic, D. Lomet, S. Martinet, and R.J. Scaramuzzi,
2016. The "ram effect": A "non-classical" mechanism for inducing LH surges in sheep. PloS one, 11: 1-22.

Ferreira-Silva J.C., F.T. Filho, M.T. Moura, P.S. Nascimento, L.R.S. Oliveira, C.C. Bartolomeu and M.A.L. Oliveira, 2018. Follicular size, luteinizing hormone $(\mathrm{LH})$, and progesterone $(\mathrm{P} 4)$ levels in postpartum Santa Inês ewes subjected to ram effect combined with suckling interruption. Livestock Science, 214: 88-92.

Ferreira-Silva, J.C., S.R.L. Basto, F. Tenório Filho, M.T. Moura, M.L. Silva Filho and M.A.L. Oliveira, 2017a. Reproductive performance of postpartum ewes treated with insulin or progesterone hormones in association with ram effect. Reproduction in Domestic Animals, 52: 610-616.

Ferreira-Silva, J.C., T.A. Burnett, P.F.M.P. Souto, L.C. Pereira, M.V. Araujo, M.T. Moura and M.A.L. Oliveira, 2017b. Progesterone (P4), luteinizing hormone (LH) levels and ovarian activity in postpartum Santa Inês ewes subject to a male effect. Archives Animal Breeding, 60: 95100.

Fierro, S., J. Gil, C. Vi noles, and J. OliveraMuzante, 2013. The use of prostaglandins in controlling estrous cycle of the ewe: A review. Theriogenology, 79: 399-408.

Fletcher I.C. and D.R. Lindsay, 1971. Effect of rams on the duration of oestrous behaviour in ewes. Journal of Reproduction and Fertility, 25: 253259. 
Folch, F., 1990. Utilizacion practica del 'efecto macho' para la provocacion de celos y ovulaciones en Ganado ovino. Information Technology Economy Agriculture, 86: 145-163.

Ganaie, B.A., M.Z. Khan, S. Qureshi, R. Islam and G.M. Wani, 2009. Plasma progesterone profile during gestation and preipartum period in Corriedale sheep. Indian Journal of Animal Reproduction, 30: 18-21.

Godfrey, R.W., J.R. Collins, E.L. Hensley and J.E. Wheaton, 1999. Estrus synchronization and artificial insemination of hair sheep in the tropics. Theriogenology, 51: 985-97.

Hawken P.A., A.P. Beard, T. Esmaili, H. Kadokawa, A.C. Evans, D. Blache and et al., 2007. The introduction of rams induces an increase in pulsatile LH secretion in cyclic ewes during the breeding seas on. Theriogenology, 68: 56-66.

Hawken, P.A.R. and G.B. Martin, 2012. Sociosexual stimuli and gonadotropin-releasing hormone/luteinizing hormone secretion in sheep and goats. Domestic Animal Endocrinology, 43: 85-94.

Homeida, A.M., A.I. AL-Mubarak and Y.M. ALYousef, 2009. Synchronization of estrus in Naeimi ewes following treatment with progesterone and prostaglandin $F_{2 \alpha}$. Scientific Journal of King Faisal University, 10: 95-103.

Jorre de St Jorre, T., P.A.R. Hawken and G.B. Martin, 2014. New understanding of an old phenomenon: uncontrolled factors and misconceptions that cast a shadow over studies of the 'male effect' on reproduction in small ruminants. Turkey Journal Veterinary Animal Science, 38: 625-636.

Lassoued, N., N. Khaldi, P. Chemineau, Y. Cognie, and J. Thimonier, 1997. Role of the uterus in early regression of corpora lutea induced by the ram effect in seasonally anoestrous Barbarine ewes. Reproduction and Nutrition Development, 37: 559-571.

Lindsay D.R., Y. Cognie, J. Pelletier and J.P. Signoret, 1975. Influence of the presence of rams on the timing of ovulation and discharge of LH in ewes. Physiology Behavior, 15: 423-426.

Martin G.B., C.M. Oldham, Y. Cognie and D.T. Pearce, 1986. The physiological response of anovulatory ewes to the introduction of rams - A review. Live Production Science, 15: 219-247.

Meilán J. and R. Ungerfeld, 2014. Does introduction of rams during the late luteal phase promote the estrus response in cyclic ewes? Small Ruminant Research, 120: 116-120.

Murtagh, J.J., D.R. Gray, D.R. Lindsay, C.M. Oldham, and D.T. Pearce, 1984. The effect of the presence of rams on the continuity of ovarian activity of maiden Merino ewes in Spring. In: Lindsay, D.R., Pearce, D.T. (Eds.), Reproduction in Sheep. Cambridge University Press, Cambridge, pp. 37-38.
Niswender, G.D., 2002. Molecular control of luteal progesterone secretion. Reproduction, 123: 333339.

Niswender, G.D., J.L. Juengel, P.J. Silva, M.K. Rollyson and E.W. McIntush, 2000. Mechanisms controlling the function and life span of the corpus luteum. Physiological Review, 80: 1-29.

NRC, National Research Council, 1985. Nutrient Requirements of Sheep. 6th ed National Academy Press, Washington DC, USA.

Romano, J.E., 1998. The effect of continuous presence of bucks on hastening the onset of estrus in synchronized does during the breeding season. Small Ruminant Research, 30: 99-103.

Romano, J.E., A. Alkar, V.O. Fuentes-Hernández and M. Marcel Amstalden, 2016. Continuous presence of male on estrus onset, estrus duration, and ovulation in estrus-synchronized Boer goats. Theriogenology, 85: 1323-1327.

Rosa, H.J.D. and M.J. Bryant, 2002. The 'ram effect' as a way of modifying the reproductive activity in the ewe. Small Ruminant Research, 45: 1-16.

Rubianes, E., A. Beard, D.J. Dierschke, P. Bartlewski, G.P. Adams and N.C. Rawlings, 1997. Endocrine and ultrasound evaluation of the response to induced ovulation at different stages of the luteal phase in cycling ewes. Theriogenology, 48: 1093-1104.

Scaramuzzi, R.J., N.R. Adams, D.T. Baird, B.K. Campbell, J.A. Downing, J.K. Findlay, K.M. Henderson, G.B. Martin, K.P. McNatty, A.S. Mcneilly and C.G. Tsonis, 1993. A model for follicle selection and the determination of ovulation rate in the ewe. Reproduction Fertility Development, 5: 459-478.

Senosy, W., G.B. Mahmoud and Sh. M. AbdelRaheem, 2017. Influence of short-term energy supplementation on estrus ovarian activity and blood biochemistry in Ossimi ewes synchronized with fluorogestone acetate in the subtropics. Theriogenology, 88: 152-157.

SPSS, 2007. Statistical package for the Social Sciences Version 13. Inc., Chicago, IL.

Ungerfeld, R. and E. Rubianes, 1999. Estrus response to the ram effect in Corriedale ewes primed with medroxyprogesterone during the breeding season. Small Ruminant Research, 32: 89-91.

Ungerfeld, R., 2003. Reproductive responses of anestrous ewes to the introduction of rams. $\mathrm{PhD}$ thesis, Swedish University of Agricultural Sciences, Uppsala, Sweden.

Ungerfeld, R., 2011. Combination of the ram effect with $\mathrm{PGF}_{2 \alpha}$ estrous synchronization treatments in ewes during the breeding season. Animal Reproduction Science, 124: 65-68.

Ungerfeld, R., A. Pinczak, M. Forsberg and E. Rubianes, 2000. Parámetros para determinar la profundidad del anestro estacional en la oveja. [Parameters to determine anestrus depth in sheep.] Quinta Reunión Latinoamericana de Cátedras de Fisiología Veterinaria, La Plata, Argentina, 14-15 de diciembre. [Fifth Latin 
American Veterinary Physiology Departments Meeting, La Plata, Argentina, December 14-15]. Ungerfeld, R., M. Forsberg and E. Rubianes, 2004.

Overview of the response of anoestrous ewes to the ram effect. Reproduction Fertility Development, 16: 479-490.

تأثير وجود الكبش على السلوك الثبقى والتراكيب المبيضيه ومستويات الهرمونات الأستيروديه فى النعاج الأوسيمى المعامله بالبروستاجلاندين (PGF 2a جمال بلري محمود'، حسن عبد الصبور على حسين'

1 ـ ـ قسم الإنتاج الحيوانسي، كلية الزراعة r ـ قسم التوليا والتناسليات والتلقيح الإصطناعى ، كلية الطب البيطرى 1 ـr - جامعة أسبيوط، مصر

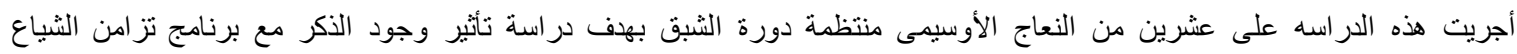

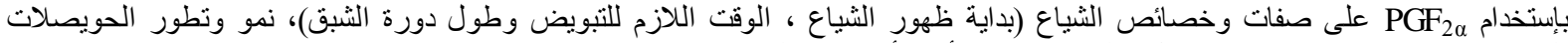

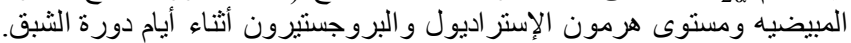

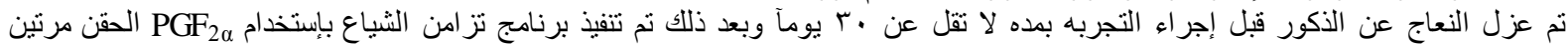

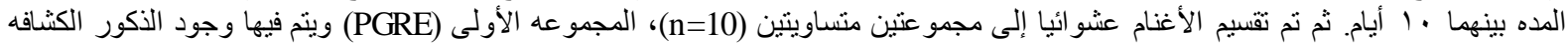

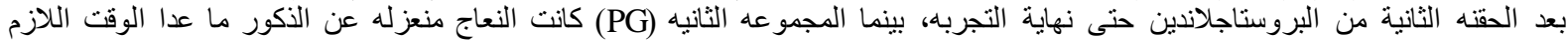

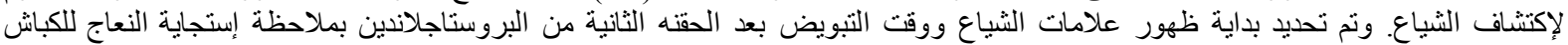

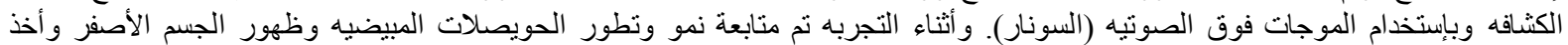

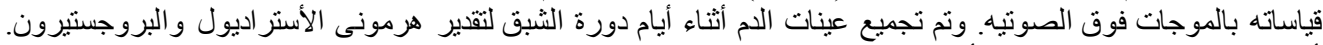

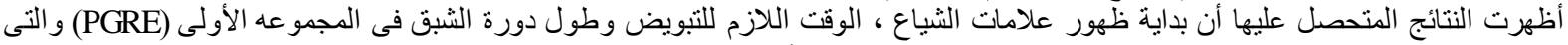

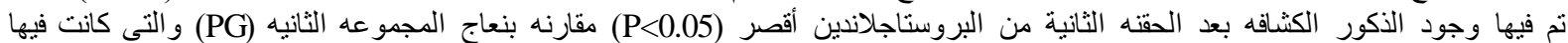

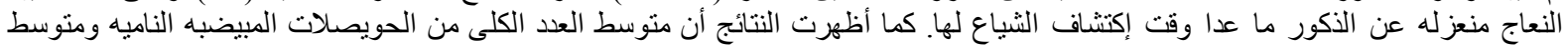

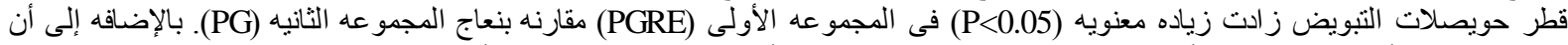

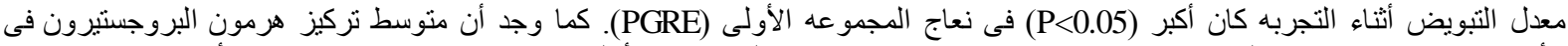

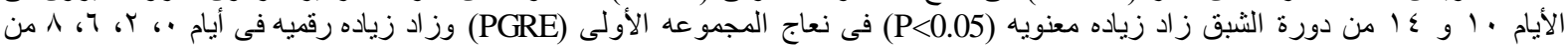

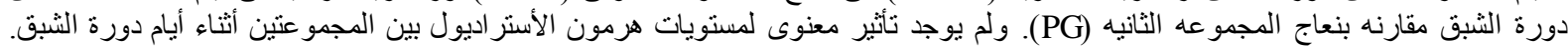

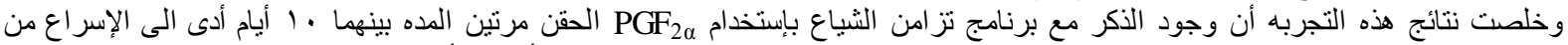

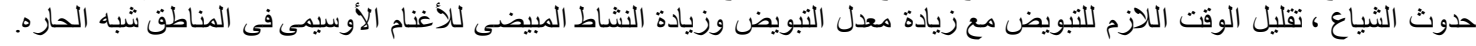

